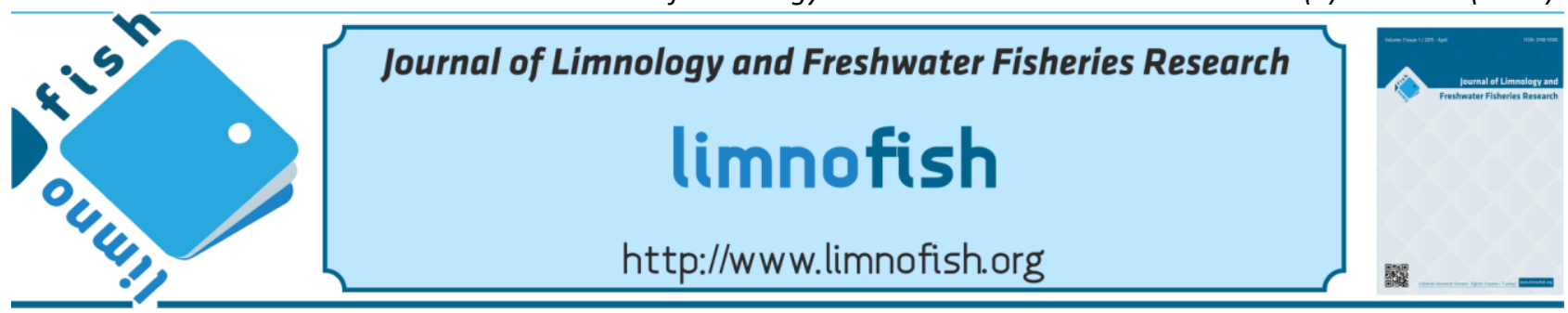

\title{
The Gastropod Fauna of the Afyon-Dinar İncirlipınar Spring, Turkey
}

\author{
Mehmet Zeki YILDIRIM ${ }^{1}$ (iD), Mustafa Emre GÜRLEK ${ }^{2 *}$ (iD) \\ ${ }^{1}$ Mehmet Akif Ersoy University, Bucak School of Health, Burdur, Turkey \\ ${ }^{2}$ Mehmet Akif Ersoy University, Burdur Vocational School of Health Services, Burdur, Turkey
}

\section{A B STRACT}

In this study 11 gastropod species belong to 2 subclass, 8 family and 11 genus (Theodoxus anatolicus, Bithynia pseudommericia, Graecoanatolica dinarica, Valvata piscinalis, Stagnicola palustris, Radix labiata, Planorbis planorbis, Planorbarius corneus, Bathyomphalus contortus, Acroloxus lacustris, Physella acuta) were determined on the Incilipınar spring which is one of the important aquatic resource of the Western Anatolian region.

Keywords: Gastropoda, İncirlipınar spring, Dinar, Turkey

\section{ARTICLE INFO}

\section{RESEARCH ARTICLE}

$\begin{array}{lll}\text { Received } & : 02.07 .2018 \\ \text { Revised } & : 06.11 .2018 \\ \text { Accepted } & : 15.11 .2018 \\ \text { Published } & : 27.08 .2019\end{array}$

DOI:10.17216/LimnoFish.439588

* CORRESPONDING AUTHOR

malacoturk@gmail.com

Phone : +902482132600

\begin{abstract}
Afyon-Dinar İncirlipınar Su Kaynağı Gastropod Faunası
Öz: Bu çalışmada, 2 altsınıf, 8 familya ve 11 cinse ait 11 Gastropod türü (Theodoxus anatolicus, Bithynia pseudommericia, Graecoanatolica dinarica, Valvata piscinalis, Stagnicola palustris, Radix labiata, Planorbis planorbis, Planorbarius corneus, Bathyomphalus contortus, Acroloxus lacustris, Physella acuta), Batı Anadolu'nun önemli bir su kaynağ1 olan İncirlipınar kaynağından tespit edilmiştir.

Anahtar kelimeler: Gastropoda, İncirlipınar kaynağı, Dinar, Türkiye

How to Cite

Yıldırım MZ, Gürlek ME, 2019. The Gastropod Fauna of the Afyon-Dinar İncirlipınar Spring, Turkey. LimnoFish. 5(2): 116-120. doi: 10.17216/LimnoFish.439588
\end{abstract}

\section{Introduction}

The different habitats emerging parallel to the geological developments that Anatolia possesses are included as a speciation area. Undoubtedly, topographic, hydrographic and consequently climatological developments are very decisive factors in this matter. In addition to all these, Anatolia has a rich flora and fauna structure. One of the faunal elements of this rich structure is the snails. Up to now, 80 prosobranch species and 28 pulmonate species have been identified in our country (Yıldırım et al. 2006a, 2006b; Yıldırım and Kebapçı 2009). Approximately half of the prosobranch are endemic.

Incirlipınar is one of the 25 major river basins of Turkey from one starting point of the Büyük Menderes River, which is one of the most important aquatic resources of Western Anatolia. This spring is situated in the Lakes Region where the western
Taurus Mountains, southwestern of Turkey. The direction change of the Taurus Mountains to the north of Antalya Bay resulted in the formation of narrow and long mountain belts surrounding depressions in which numerous lakes and springs were formed. Along with these, this special and sensitive area is under intense threat due to fisheries and agricultural activities. We have been communicating with the relevant institutions for the protection of this area but have not received any results.

\section{Materials and Methods}

This study is conducted to determine Gastropod fauna of the Afyon-Dinar İncirlipınar Spring (38.053417 N, 30.176666 E) (Figure 1), on 5 representative stations date of September 2016. The snails were collected with an aquatic hand-scoop, which was $65 \times 65 \mathrm{~cm}$ in size and had a $200 \mu \mathrm{m}$ mesh 
from the banks of the water. They preserved in plastic tubes, including 80\% ethanol. Dissections and measurements of the shells and genital organs were carried out using a stereomicroscope (Olympus SZX7) and photographs were taken with a digital camera system (Olympus DP26).

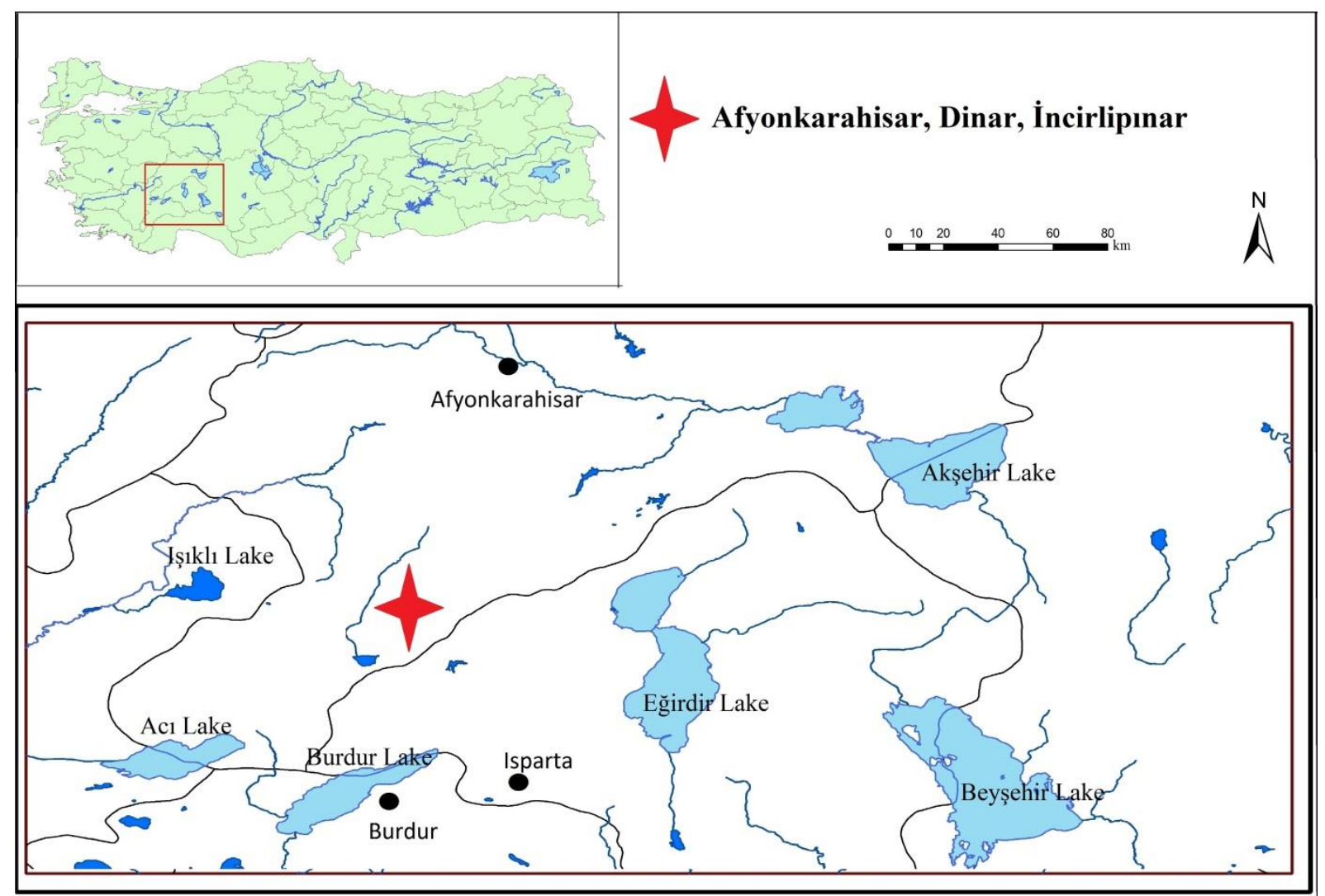

Figure 1. Map of the studying area.

\section{Results}

A total of 11 Gastropoda species belong to 2 subclasses, 8 families and 11 genera were found in this study.

Class: Gastropoda

Subclass: Neritimorpha

Order: Cycloneritimorpha

Superfamily: Neritoidea

Family: Neritidae

Genus: Theodoxus

Theodoxus anatolicus Recluz, 1841 (Figure 2a)

This species restricted to the coastal areas of Turkey, where it is common. It also occurs in middle Anatolia. According to Red List Category \& Criteria, this species accepted as near threatened. There are intensive agriculture and fishing activities especially in this aquatic area and its vicinity. Changes in the bed of the weld and its extension are made from time to time. Again, this is a field that is open to human influences and is rapidly polluted, so there is a serious danger for susceptible species, especially for this species.

Subclass: Heterobranchia

Superfamily: Valvatoidea

Family: Valvatidae

\section{Genus: Valvata}

Valvata piscinalis O. F. Müller, 1774 (Figure 2d)

This species is known as one of the most common Euro-Siberian freshwater snails (Glöer 2002). It is resistant to a moderate degree of pollution and eutrophication. Locality is within an agricultural area until recently used as a recreational area and then as a fish farm. The high level of eutrophication currently observed in the pond is indicative of excessive organic pollution. Thus, it is an appropriate habitat for these species. It has distributed in large freshwater lakes, ponds, and springs in Western Anatolia, Marmara, and Mediterranean regions.

Order: Littorinimorpha

Superfamily: Truncatelloidea

Family: Bithyniidae

Genus: Bithynia

Bithynia pseudemmericia Schütt, 1964 (Figure 2b)

This species lives on the bottom and aquatic vegetation, and they prefer standing water. According to Red List Category \& Criteria, this species accepted as vulnerable. It has distributed in large freshwater lakes, ponds, and springs in Western Anatolia and Marmara Region. It is also an 
interesting zoogeographic record that the Hazar Lake (Elazığ) has also distributed. The hypothetical Big Inner Lake, thought to be influential in the distributed of freshwater gastropods in Anatolia, partially explains the survival of this species at very far distances. Because the aquatic systems located between the Hazar Lake and the Lake District do not yet have any records about this species (Yildirim et al. 2006b). Therefore, it is thought that the distributed of the product may have been accompanied by anthropogenic effects such as fishing activities.

Family: Hydrobiidae

\section{Genus: Graecoanatolica}

Graecoanatolica dinarica Kebapçı et al. 2012 (Figure 2c)

This species is endemic to İncirlipınar and Ulupınar springs at the headwaters of Büyük Menderes River. The two sites (Ulupinar spring in Çapalı Lake and İncirlipınar pond) are hydrologically connected. This species is endangered (EN) in Red List Category \& Criteria of IUCN. Graecoanatolica Radoman 1973 is distributed between Macedonia, Greece (Thessaly), and Turkey (Lakes Region). However, the current distribution of the genus is restricted to Turkey, as the 2 Balkan species have been declared extinct. G. conica Radoman, 1973 and G. brevis Radoman, 1973 from the provinces of Denizli and Burdur are determined to be extinct (Kebapç1 et al. 2012). Species known to distribution in Turkey are: Graecoanatolica lacustristurca Radoman 1973, Graecoanatolica tenuis Radoman 1973. Graecoanatolica kocapinarica Radoman 1973, Graecoanatolica pamphylica Schütt 1964, Graecoanatolica anatolica Schütt 1965, Graecoanatolica brevis Radoman 1973, Graecoanatolica conica Radoman 1973, Graecoanatolica nageli Glöer and Pešić, 2015, Graecoanatolica yildirimi Glöer and Pešić, 2015.

Order: Hygrophila

Superfamily: Lymnaeoidea

Family: Acroloxidae

Genus: Acroloxus

Acroloxus lacustris Linnaeus, 1758 (Figure 2k)

This small freshwater limpet inhabits clean water in canals, slow lowland rivers, lakes and drainage ditches, and small ponds. It is usually found attached to vegetation (leaves and stems of aquatic plants) or dead submerged wood and sometimes large freshwater mussel shells. It is generally a calciphile, although tolerant of soft water. In the ancient lakes of Ohrid (Balkan region) and Lake Eğirdir, Turkey, Shirokaya et al. (2012) report that A.lacustris does not inhabit the lakes where the endemic species are found, but it is present in the rivers and ponds in the surrounding catchment areas.

Family: Lymnaeidae

Genus: Radix

Radix labiata Rossmässler, 1835 (Figure 2h)

This species was known as Radix peregra until 2001, after this year peregra is only used in outdated classifications in the meaning of $R$. labiata (WelterSchultes 2012). They live in standing or slowly running small waters on a muddy substrate with vegetation. This species is widespread from Middle Europe to Southern Europe (Glöer 2002; WelterSchultes 2012), also nearly all regions of Turkey.

\section{Genus: Stagnicola} 2j)

Stagnicola palustris O. F. Müller, 1774 (Figure

This species is widespread and common Palearctic species (Glöer 2002). However, they can be found nearly in all mostly in permanent waters have rich vegetation, in pools, lakes, ponds, wetlands and along rivers. This species was found in all the regions studied in Turkey.

Family: Physidae

Subfamily: Physinae

Physella acuta Draparnaud, 1805 (Figure 2i)

This species is found in a wide range of natural and anthropogenic water types, including polluted water and distributing in the Aegean Region, the Mediterranean Region, the Central Anatolia Region, the Black Sea Region, the Southeastern Anatolia Region and also in Mediterranean (Zhadin 1965), Northern Caucasus, Central Europe (Yildırım et al. 2006a).

Family: Planorbidae

Genus: Planorbis

Planorbis planorbis Linnaeus, 1758(Figure 2e)

It has found nearly all kind of inland water body types but shows a preference for standing water, such as ponds, swamps or lakes with slow-moving or stagnant water systems. This species is Palearctic (Glöer 2002; Welter-Schultes 2012), also distributing nearly all regions of Turkey.

Subfamily: Planorbinae

Genus: Planorbarius 2f)

Planorbarius corneus Linnaeus, 1758 (Figure

The largest planorbiid snail in freshwater systems. They inhabit so slow running waters, edge of pools, lakes on a variety of substrates. We have seen mostly this species and Lymnaea stagnalis live together in the same habitats. These species are distributed in Europe to 
western Siberia (Glöer 2002; Welter-Schultes 2012). Also West part, Middle Anatolia and South part of Anatolia.

Genus: Bathyomphalus

Bathyomphalus contortus Linnaeus, 1758 (Figure 2g)
They live in permanent standing water systems with rich vegetation. This species has a Palearctic distribution occurring throughout Europe and Russia to Siberia (Glöer 2002, Welter-Schultes 2012). In Turkey, there are a few isolated records reported from Egirdir and Dinar by Yıldırım (1999) and Yıldırım and Kebapçı (2009).

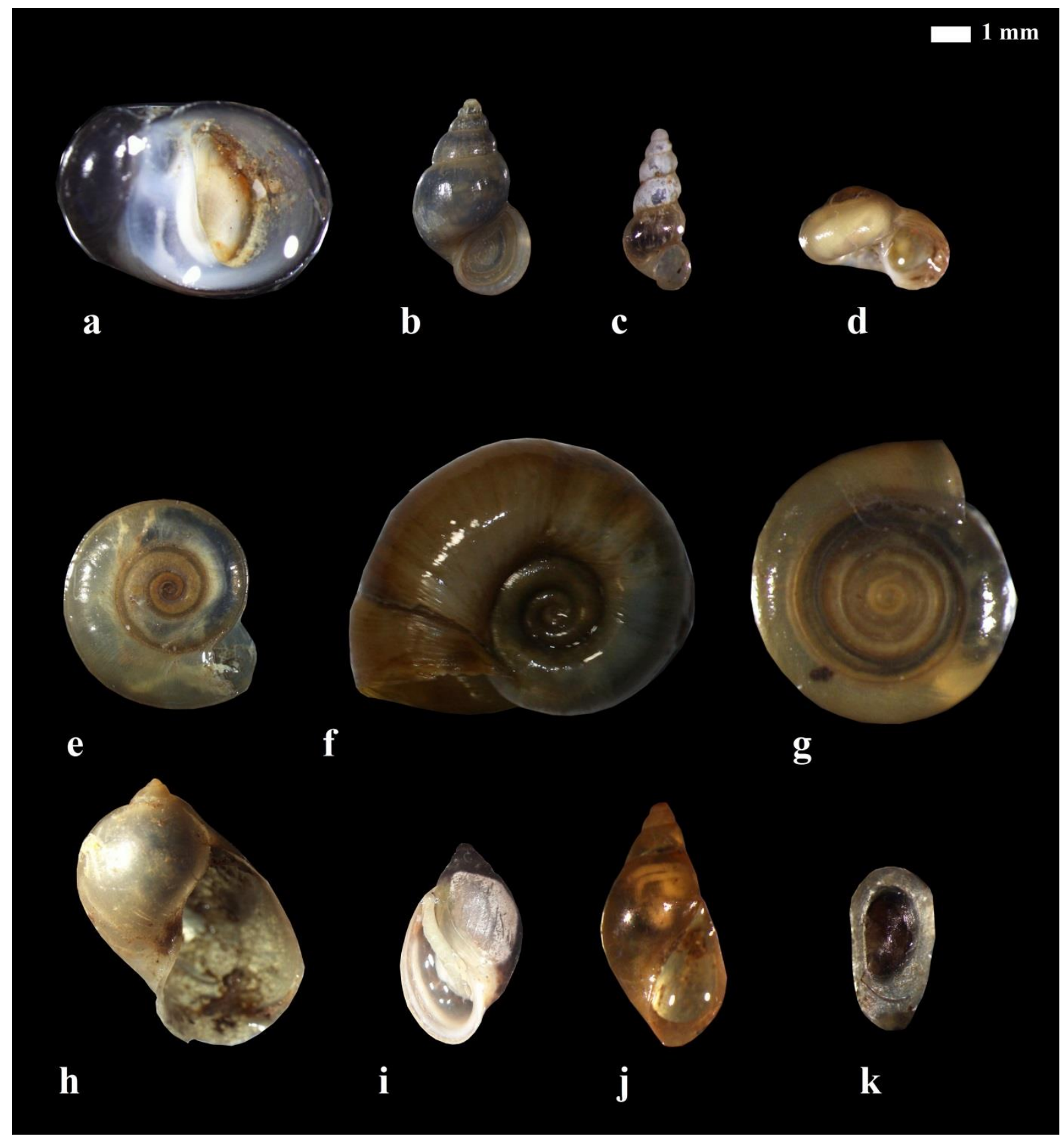

Figure 2. Gastropods of İncirlipınar spring. a. T. anatolicus b. Bithynia pseudemmericia c. G. dinarica d. Valvata piscinalis e. P. planorbis f. P. corneus g. B. contortus h. R. labiata i. P. acuta j. S. palustris k. A. lacustris.

\section{Discussion}

İncirlipınar freshwater spring, small pond, and its extension, are one of the important biological areas of the Lakes Region of Turkey. Up to now, 11 snail species have been identified in this system. One of these is locally endemic and live only in this system and in their connections ( $G$. dinarica). Also other endemic species of Anatolia T. anatolicus, Bithynia pseudommericia are living in this habitat. In a sense, locality is a center of speciation for aquatic snails. But this locality is within an agricultural area until recently, used as a recreational area and then as a fish farm. The high level of eutrophication currently observed in the pond is indicative of excessive 
organic pollution. With all this, it is believed that this biologically important area and the living creatures must be protected.

\section{References}

Glöer P. 2002. Die Süsswassegastropoden Nord- und Mitteleuropes. Deutschland: Gustav Fischer Verlag, Jena $327 \mathrm{p}$.

Glöer P, Pesic V. 2015. Two new freshwater mollusk species of the genus Graecoanatolica Radoman, 1973 from Turkey (Gastropoda: Hydrobiidae). Ecologica Montenegrina. 4: 46-51.

Kebapçı Ü, Bahadır Koca S, Yıldırım, MZ. 2012. Revision of Graecoanatolica (Gastropoda: Hydrobiidae) species in Turkey. Turk J Zool. 36(4):399-411. doi: 10.3906/zoo-1011-10

Shirokaya A, Kebapçı Ü, Hauffe T, Albrecht C. 2012. Unrecognized biodiversity in an old lake: a new species of Acroloxus Beck, 1837 (Pulmonata, Hygrophila, Acroloxidae) from Lake Eğirdir, Turkey. Zoosyst Evol. 88(2):159-170. doi: 10.1002/zoos.201200014

Welter-Schultes F. 2012. European non-marine molluscs, a guide for species identification. Göttingen: Planet Poster Editions 760 p.

Yıldırım MZ. 1999. Türkiye Prosobranchia (Mollusca: Gastropoda) türleri ve zoocoğrafik yayılışları. 1. tatlı ve ac1 sular. Turk J Zool. 23: 877-900.

Yıldırım MZ, Gümüş BA, Kebapçı Ü, Bahadır Koca S. 2006a. The Basommatophoran Pulmonate species (Mollusca: Gastropoda) of Turkey. Turk J Zool. 30:445-458.

Yıldırım MZ, Koca SB, Kebapçı Ü. 2006b. Supplement to the Prosobranchia (Mollusca: Gastropoda) fauna of Fresh and Brackish Waters of Turkey. Turk J Zool. 30:197-204.

Yıldırım MZ, Kebapçı Ü. 2009. Endemism of land and freshwater gastropods in the Lakes region (Turkey). Muzeul Olteniei Craiova, Studii şi communicãri, Ştiinjele Naturii. 25: 55-59.

Zhadin VI. 1965. Moluscs of Fresh and Brackish waters of U.S.S.R. Jerusalem: Israel Program for Scientific Translations 368 p. [in Russian] 